\title{
University of California faces drastic cuts
}

Proposed budget reductions may force closure of whole campuses and medical schools, writes John H. Douglas from San Francisco

RESPONDING to strong popular sentiment against high levels of government spending, California governor Edmund G. Brown, Jr., has demanded that all state agencies submit a list of programmes that can be cut immediately in order to bring about a $10 \%$ reduction in next year's budget.

Such cuts could drastically affect the prestige and research capability of the 9-campus University of California, which accepts students from the top $12.5 \%$ of the state's high school graduates. More students, however, would be affected by reductions in the 19-campus State University and Colleges system, which accepts students from the top one-third of high school classes, and in the 106 state-supported Community Colleges, which presently are open to any resident 18 years of age or older.

In a strongly worded reply to the governor's demands, University of California president David S. Saxon said flatly that spending reductions of this magnitude simply could not be accomplished by next year if the university were to honour its commitments to present students and to contracts with external agencies. Even to reduce the budget over the next three to five years, he said, would require closing a combination of campuses, medical schools and associated research institutes.

However, one of the factors cited by Governor Brown in defence of his proposed cuts is that during his past four year term the budget for the State University and Colleges has risen by $44.4 \%$ over the cost of living, although enrolment has dropped $2.6 \%$. Such declines can be expected to continue, since a $25 \%$ reduction in the college-age population is expected over the next decade.

Saxon nevertheless warned the governor that to cut $10 \%$ (or about $\$ 77$ million) in state support would translate into a much larger reduction in the overall university budget, since many programmes receive an equal amount of funding from other sources. Especially hard hit would be the science programmes that receive large research grants from the Federal government. "The number of jobs lost would be more than doubled", Saxon said.

To make matters even worse, the proposed reductions would come just at a time when the university has already suffered a $\$ 31$ million cut in its proposed budget, following passage of Proposition 13 in this year's elections (which substantially reduced property taxes). And university employees did not receive any salary increases this year, putting them at the mercy of $8 \%$ inflation and setting the university a year behind many other institutions. Unless salary increases come soon, says Saxon, "our base would be so low that we would be unable to offer competitive salaries to any employees, and especially faculty, for the foreseeable future".

If major units of the University of California must be closed, speculation has centred on the vulnerability of the two smallest non-specialised campuses, at Riverside and Santa Cruz. The campuses suffered enrolment decreases this year of $5 \%$ and $3.5 \%$ respectively, compared to an increase in overall university enrolment of $1.5 \%$. Riverside was upgraded from an agricultural institute and has never enjoyed the prestige of older campuses. Santa Cruz is remotely located and uses a controversial student evaluation

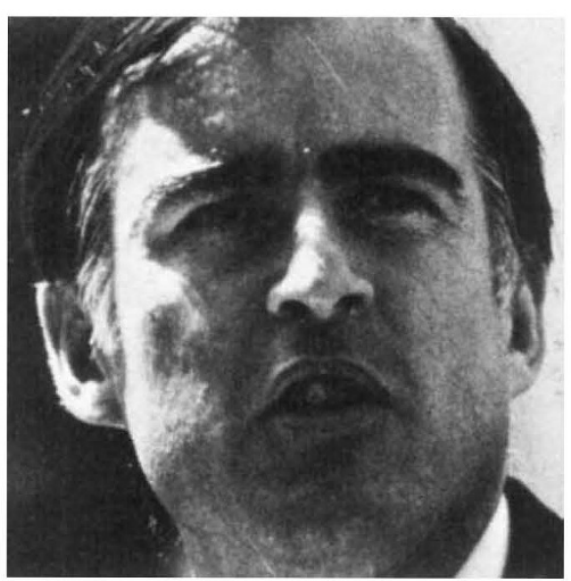

Governor Brown : cuts all round

system. Closing either unit would require special legislation, however.

Other solutions under discussion would also require new legislation and, perhaps more important, the cooperation of the governor. Rather than cutting expenses, as directed, the university could be made more independent of state treasury funds by increasing student fees. California now supports the only system of higher education in the United States that is theoretically tuition free, although students pay about $\$ 700$ a year in "fees". Increasing such fees by $\$ 100$ a quarter (or imposing tuition of that amount) could raise nearly $\$ 35$ million for the university. Proponents of this idea point out that more long-term loans are now available to middle class families than when the tuition-free system was originally set up. Raising admissions standards might also help relieve pressure on the university.

Population decreases and rising fees are likely to hit hardest at the Community Colleges, where competition for entrance is not so keen. Enrolment in normal credit courses declined $4 \%$ this year, although it was originally expected to rise $3 \%$. And when new fees were added last fall to non-credit courses (which attract older students not working toward a degree), enrolment in such courses plunged $40 \%$.

All of these problems are likely to come to a head next spring when the California legislature considers the state budget. The eventual outcome is likely to hinge on details of a political process that may seem quaint even by California's arcane standards. Although the universities and colleges have powerful friends in the legislature, the governor has authority to veto specific budget items and could thus eliminate individual programmes he dislikes. And, for the first time in this century, California's governor and lieutenant governor belong to different parties. The new Republican lieutenant governor, Mike Curb, has strongly hinted he will oppose Democrat Brown on the university issue. What this would mean remains unclear.

Finally, several legal questions remain unresolved. By custom, faculty tenure at the University of California has been considered to apply only on one campus. If campuses were eliminated, the future of tenured faculty would be cast into doubt, as would the university's reputation as a desirable institution with which to affiliate. Longterm research contracts between university institutes and Federal funding agencies would also be threatened.

In assessing the possible impact of the proposed budget cuts, some of the most vigorous and articulate support for the University of California has come from the president of a competing private institution: Richard W. Lyman of Stanford University. Calling the University of California system "the greatest publically supported university in the country", Lyman said: "Californians have gone to considerable lengths to try to protect this uniquely fine university from being converted into a mere arm of government. It would be a sad irony indeed if, in the effort to trim government down to defensible size, the university were to be damaged in ways that would require many years of painstaking work to correct, if indeed they could be remedied at all". 